\title{
Effects of hyperglycaemia and sorbitol accumulation on erythrocyte deformability in diabetes mellitus
}

\author{
D BAREFORD, ${ }^{*}$ PE JENNINGS, $\dagger$ PCW STONE, ${ }^{*}$ S BAAR, ${ }^{*}$ AH BARNETT, $\dagger$ \\ J STUART*
}

From the *Department of Haematology, Medical School, University of Birmingham, and the †Department of Medicine, East Birmingham Hospital, Birmingham

SUMMARY Erythrocyte deformability was studied in a total of 83 poorly controlled diabetics (mean blood glucose $12.2 \mathrm{mmol} / \mathrm{l}$ ) who were divided into three groups, each with matched healthy controls. There was no appreciable difference between diabetics and matched controls regarding the filtration of erythrocytes through $3 \mu \mathrm{m}$ diameter straight channel pores ( 25 diabetics) or tortuous channel $\mathbb{N}$ pores (28 diabetics), or for the measurement of erythrocyte elongation over a range of osmolalities 9 in the Ektacytometer ( 30 diabetics). When erythrocytes from 17 additional diabetics and 17 healthy $\vec{c}$ controls were incubated for two hours at $37^{\circ} \mathrm{C}$ in hyperglycaemic $(50 \mathrm{mmol}$ glucose/l) buffer, however, there was a considerable reduction in erythrocyte filterability for both diabetics and controls $\vec{\circ}$ in parallel with an increase in erythrocyte sorbitol concentration. This loss of filterability was $\infty$ prevented by the addition of an aldose reductase inhibitor (Sorbinil). High glucose concentrations: ( $\simeq 50 \mathrm{mmol} / \mathrm{l})$ impair the filterability of erythrocytes through $3 \mu \mathrm{m}$ pores, and the intracellular accumulation of sorbitol in poorly controlled outpatients is therefore unlikely to have a major adverse effect on erythrocyte rheology in diabetes mellitus.

Erythrocytes from uncontrolled diabetics were originally found to have impaired deformability when suspended in autologous plasma and filtered through $5 \mu \mathrm{m}$ diameter pores. ${ }^{1}$ It was subsequently suggested that the impaired erythrocyte filterability could be corrected in vivo and in vitro by the addition of insulin. ${ }^{2}$ Several factors extrinsic to the erythrocyte, however, may contribute to this impairment of filterability in uncontrolled diabetes. These include an acute phase increase in plasma fibrinogen concentration ${ }^{3}$; leucocytosis ${ }^{4}$; plasma hyperosmolality, ${ }^{35}$ which can increase erythrocyte mean cell haemoglobin concentration; and a low blood $\mathrm{pH}^{6}$ or low plasma sodium concentration, ${ }^{7}$ which can increase erythrocyte mean cell volume.

The individual rheological effects of these extrinsic factors can be studied by resuspending leucocyte depleted washed erythrocytes in an appropriate buffer. In two earlier studies normal erythrocytes suspended in hyperglycaemic buffer showed impaired filtration through $5 \mu \mathrm{m}$ diameter pores. ${ }^{89}$ As water crosses the erythrocyte membrane in milliseconds ${ }^{10}$ and glucose loss from the cell has a half life of $<30$ seconds, ${ }^{1112}$ hyperglycaemia of plasma or buffer is unlikely to impair erythrocyte rheology by a simple

Accepted for publication 26 February 1986 osmotic effect. Human erythrocytes can respond to a hyperglycaemic environment, however, by forming $\overrightarrow{\overrightarrow{0}}$ intracellular sorbitol, ${ }^{1314}$ and as sorbitol does not 3 readily diffuse out of cells its concentration in the diabetic erythrocyte is raised. ${ }^{15}$ Accumulation of sorbitol via the polyol pathway could thus affect the osmotic properties and consequently the deformability of erythrocytes:

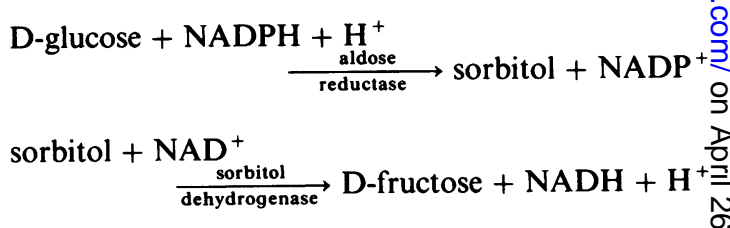

where $\mathrm{NADP}^{+}=$nicotinamide adenine dinucleotiden phosphate and $\mathrm{NAD}^{+}=$nicotinamide adenine
dinucleotide.

Intracellular accumulation of sorbitol in diabetic has previously been implicated in the development of cataracts, ${ }^{16}$ peripheral neuropathy, ${ }^{17}$ and arteria ${ }_{0}$ wall lesions. ${ }^{18}$ We therefore compared the rheolog 5 of erythrocytes from poorly controlled outpatien diabetics, with that of matched controls, and we alsof investigated the rheological effect of incubating? diabetic and normal erythrocytes in high concen? 
trations of glucose in vitro with and without inhibition of the polyol pathway by the aldose reductase inhibitor Sorbinil.

\section{Methods}

\section{PATIENT GROUPS}

Rheological measurements were performed on poorly controlled outpatient diabetics, with a mean blood glucose concentration for the 83 patients of $12 \cdot 2 \mathrm{mmol} / \mathrm{l}$ (range 2.4-28.1). Table 1 gives the clinical and biochemical data.

Erythrocyte filtration ( $3 \mu \mathrm{m}$ polycarbonate membrane) Twenty five poorly controlled, insulin dependent diabetics ( 11 men; mean age 46.0 years, range $21-78$ ) were matched for age and sex with 25 healthy controls (11 men; mean age $40 \cdot 7$ years, range 17-86).

Erythrocyte filtration ( $3 \mu \mathrm{m}$ silver membrane) Twenty eight diabetics (14 insulin dependent; 17 men; mean age 49.4 years, range 17-70) were matched for age and sex with 28 healthy controls ( 17 men; mean age 48.4 years, range $21-68$ ).

Laser viscodiffractometry Thirty diabetics (14 insulin dependent; 19 men; mean age 47.9 years, range 19-72) were matched for age and sex with 30 healthy controls ( 19 men; mean age $45 \cdot 9$ years, range 20-69).

Blood samples for rheological tests were taken from an antecubital vein into lithium heparin (15 IU $/ \mathrm{ml}$ blood; Sterilin Ltd, Feltham, Middlesex) and analysed within four hours. ${ }^{19}$

A pure suspension of washed erythrocytes was prepared for filtration studies by passage of whole blood through Imugard IG500 cotton wool (Terumo Corporation, Tokyo, Japan) followed by two washes in phosphate buffered saline $(75 \mathrm{mmol} / 1$ phosphate) of pH 7.4 and osmolality $290 \mathrm{mmol} / \mathrm{kg} .{ }^{20}{ }^{21}$ Erythrocyte filtration was measured by the initial flow rate method using a Hémorhéomètre SPO2 (IMH, 95470 St Witz, France) with water jacket. Filtration membranes comprising disposable straight channel polycarbonate membranes (Nuclepore Corporation, Pleasanton, California, United States of America) of $3 \mu \mathrm{m}$ (batch 62A2 B26) measured pore diameter, ${ }^{22}$ and sintered silver Selas/Hytrex membranes with tortuous channels (Osmonics Inc, Minnetonka, Minne- sota, United States of America) of nominal $3 \mu \mathrm{m}$ diameter (batch 013) were used; the latter were cleaned by ultrasonication in aqueous sodium dodecyl sulphate ${ }^{23}$ and reused. Filtration results were expressed as an index of filtration (IF) after correction for haematocrit, ${ }^{24}$ as measured by a Coulter $S$ counter (Coulter Electronics Ltd, Luton); IF values were also expressed as a percentage change in the in vitro study (Table 2). An increase in IF corresponds to a loss of filterability (reduction in deformability).

Laser viscodiffractometric measurements of erythrocyte elongation were made at ambient temperature using the Ektacytometer (Technicon International Division, Saint Denis, France), as previously described. ${ }^{25}$ Whole blood was sampled by the Ektacytometer in the clinical study and an osmotic deformability profile, or Osmoscan plot, ${ }^{26}$ was obtained by measuring erythrocyte elongation at a shear stress of $14 \mathrm{~Pa}$ in a continuously increasing osmotic gradient $(80-500 \mathrm{mmol} / \mathrm{kg})$ to give the following valves:

EI $\max =$ maximum value for erythrocyte elongation adjusted for mean cell volume $^{27}$

$\mathrm{O} \max =$ osmolality at EI $\max$

$\mathrm{O} \min =$ osmolality at which erythrocyte elongation reached its minimum in hypotonicity

O hyper $=$ osmolality at which erythrocyte elongation decreased to half the EI max value in the hypertonic arm of the curve.

In the clinical studies erythrocyte mean cell volume was measured using a Coulter S Plus IV counter; blood glucose by a glucose oxidase method using blood anticoagulated with sodium fluoride; and haemoglobin $A_{1}\left(\mathrm{Hb} \mathrm{A}_{1}\right)$ by affinity chromatography (Glycogel B; Pierce UK Ltd, Cambridge). ${ }^{28}$

In vitro incubation of erythrocytes (from 17 poorly controlled, insulin dependent diabetics and 17 healthy controls) was performed under hyperglycaemic conditions using Imugard IG500 filtered and washed erythrocytes resuspended at $0.07(7 \%)$ haematocrit in phosphate buffered saline. Incubation was performed with added D-glucose (Analar grade, BDH Chemi-

Table 1 Mean (range) values for clinical and biochemical data in the three groups of diabetics in clinical study

\begin{tabular}{|c|c|c|c|}
\hline & $\begin{array}{l}\text { Hémorhéomètre } \\
\text { polycarbonate membranes } \\
(n=25)\end{array}$ & $\begin{array}{l}\text { Hémorhéomètre } \\
\text { silver membranes } \\
(n=28)\end{array}$ & $\begin{array}{l}\text { Ektacytometer } \\
(n=30)\end{array}$ \\
\hline $\begin{array}{l}\text { Duration of diabetes (years) } \\
\text { Blood glucose }(\mathrm{mmol} / \mathrm{l})^{*} \\
\text { Erythrocyte } \mathrm{Hb} \mathrm{A}_{1}(\%) \\
\text { Erythrocyte mean cell volume (fi) }\end{array}$ & $\begin{array}{l}9 \cdot 3(1-23) \\
14 \cdot 1(6 \cdot 4-28 \cdot 1) \\
14 \cdot 7(7 \cdot 6-22 \cdot 2) \\
88 \cdot 6(81-98)\end{array}$ & $\begin{array}{l}6 \cdot 8(1-20) \\
11.9(2 \cdot 4-25 \cdot 3) \\
11 \cdot 8(6 \cdot 2-17 \cdot 8) \\
87.4(79-95)\end{array}$ & $\begin{array}{l}7 \cdot 8(1-42) \\
10 \cdot 8(3 \cdot 1-27 \cdot 6) \\
11 \cdot 3(6 \cdot 2-16 \cdot 7) \\
86 \cdot 8(74-95)\end{array}$ \\
\hline
\end{tabular}

*1 mmol/l glucose $=18 \mathrm{mg} / 100 \mathrm{ml}$. 
Table 2 Results of clinical study showing mean

(SEM) values for Hémorhéomètre and Ektacytometer in diabetic patients and matched controls

\begin{tabular}{|c|c|c|c|}
\hline & $\begin{array}{l}\text { Diabetic } \\
\text { patients }\end{array}$ & $p$ value & $\begin{array}{l}\text { Healthy } \\
\text { controls }\end{array}$ \\
\hline \multicolumn{4}{|c|}{ Hémorhéomètre IF (No of matched pairs) } \\
\hline $\begin{array}{l}3 \mu \mathrm{m} \text { silver } \\
\text { membranes }(25)\end{array}$ & $97 \cdot 2(3 \cdot 3)$ & NS & $104 \cdot 0(4 \cdot 3)$ \\
\hline membranes (28) & $61 \cdot 6(2 \cdot 2)$ & NS & $61 \cdot 8(2 \cdot 8)$ \\
\hline \multicolumn{4}{|c|}{ Ektacytometer (No of matched pairs) } \\
\hline$E I \max (30)$ & $0.55(0.01)$ & NS & $0.55(0.01)$ \\
\hline
\end{tabular}

cals Ltd, Poole) at concentrations of 5, 25, and $50 \mathrm{mmol} / \mathrm{l}$ giving final osmololities of 295,315 , and $340 \mathrm{mmol} / \mathrm{kg}$, respectively. After incubation at $37^{\circ} \mathrm{C}$ for two hours erythrocyte filtration through polycarbonate membranes of $3 \mu \mathrm{m}$ pore diameter was measured at $25^{\circ} \mathrm{C}$ using the Hémorhéomètre. Ektacytometric measurements were performed at ambient temperature on the same samples of washed erythrocytes.

A further in vitro incubation experiment was performed using Imugard IG500 prefiltered and washed erythrocytes from 17 healthy controls. Incubation was performed in phosphate buffered saline with added D-glucose at 5 and $50 \mathrm{mmol} / 1$ with and without $5 \mu \mathrm{g} / \mathrm{ml}$ Sorbinil (Pfizer Central Research, Sandwich). Erythrocytes from eight additional controls were similarly incubated in phosphate buffered saline with D-glucose ( 5 and $50 \mathrm{mmol} / \mathrm{l}$ ) but with and without $200 \mu \mathrm{U} / \mathrm{ml}$ insulin (Actrapid MC; Novo Laboratories Ltd, Basingstoke).

Before and after the above incubations osmolality (Advanced Osmometer Model 3W, Advanced Instruments Inc, Needham Heights, Massachussets, United States of America); $\mathrm{pH}$; erythrocyte morphology (interference microscopy of erythrocytes fixed in $1.25 \% \mathrm{w} / \mathrm{v}$ glutaraldehyde in phosphate buffered saline); and erythrocyte indices (calculated from Coulter S Plus IV erythrocyte count and haemoglobin concentration and centrifuged microhaematocrit) were determined for all erythrocyte suspensions. Sorbitol estimations were made on representative samples from diabetics and controls at the end of the incubation period using a modified enzymatic method, ${ }^{15}$ in which sorbitol dehydrogenase was used to convert sorbitol to fructose with measurement of the stoicheiometrically produced NADH.

Significance (two tail) was determined by the Mann-Whitney $U$ test for comparison between diabetics and healthy controls and by Wilcoxon's signed rank test for comparison of in vitro paired samples.
Bareford, Jennings, Stone, Baar, Barnett, Stuart

Results

Table 1 shows clinical and biochemical details of the three patient groups studied. In this clinical studys? the filtration of diabetic erythrocytes through $3 \mu \mathrm{mo}$ straight channel polycarbonate membranes (250 patients), or through $3 \mu \mathrm{m}$ tortuous channel silver membranes (28 patients) was not significantly ${ }_{\Omega}$ different from the filtration of erythrocytes from healthy matched controls (Table 2). When erythrocyte elongation (EI max) in the Ektacytometer was measured, there was also no significant difference between 30 diabetics and their matched controls. Theo Ektacytometer Osmoscan curve valves, $\mathrm{O}$ min, $\mathrm{O}$ $\max$, and $\mathrm{O}$ hyper also showed no significantew difference between diabetics and controls (data not shown). Erythrocyte mean cell volume did not differ significantly between patients and controls in any oN the three clinical groups.

In vitro incubation of diabetic erythrocytes in ahigher $(50 \mathrm{mmol} / \mathrm{l})$ glucose concentration for two hours resulted in pronounced accumulation of eryth rocyte sorbitol, the concentration increasing from $\overrightarrow{0}$ $1-5 \mu \mathrm{mol} / \mathrm{l}$ to $>100 \mu \mathrm{mol} / \mathrm{l}$ erythrocytes. This increase was associated with a significant $(p<0.02)$ reduction in erythrocyte filterability through $3 \mu \mathrm{m}$ diameter straight channel pores compared with filterability after incubation in $5 \mathrm{mmol} / \mathrm{l}$ glucose (Table 3). Incubation in $25 \mathrm{mmol} / 1$ glucose did not cause a significant loss of erythrocyte filterability When normal erythrocytes were similarly incubated for two hours in $50 \mathrm{mmol} / \mathrm{l}$ glucose (Table 3), there was again a pronounced increase in sorbitol accumu lation to $>100 \mu \mathrm{mol} / 1$ erythrocytes, together with a. significant $(p<0.01)$ reduction in their filterabilit原 compared with incubation in $5 \mathrm{mmol} / 1$ glucose (Tablè 3). Incubation in $25 \mathrm{mmol} / \mathrm{l}$ glucose again had no. effect on erythrocyte filtration. At a glucose concen tration of $50 \mathrm{mmol} / 1$ glucose, the erythrocytes from healthy controls showed a quantitatively greater loss of filterability $(p<0.025)$ than the erythrocytes from diabetics (Table 3). Values for EI max, measured by the Ektacytometer, were not significantly differen between the three glucose concentrations (Table 3)? and the Ektacytometer Osmocan curve variables (O min, $O$ max, and $O$ hyper) were also not్ significantly different (data not shown).

When erythrocytes from an additional 17 healthy controls were incubated for two hours in $50 \mathrm{mmol} / \mathrm{F}$ glucose there was an almost identical $(12 \%-13 \% \%$ loss of erythrocyte filterability through $3 \mu \mathrm{m}$ diameter straight channel pores compared with the loss tha occurred with incubation in $5 \mathrm{mmol} / 1$ glucose (Table 4). Addition of $5 \mu \mathrm{g} / \mathrm{ml}$ Sorbinil to the hypere glycaemic buffer prevented this loss of filterability (Table 4). In contrast, when $200 \mu \mathrm{U} / \mathrm{ml}$ insulin was 
Table 3 Results of in vitro study showing mean (SEM) values for Hémorhéomètre and Ektacytometer following two hours' incubation of erythrocytes in hyperglycaemic buffer

\begin{tabular}{|c|c|c|c|c|c|}
\hline & \multicolumn{5}{|c|}{ Glucose concentration ( $\mathrm{mmol} / \mathrm{l}$ ) } \\
\hline & 5 & $p$ value & 25 & $p$ value & 50 \\
\hline \multicolumn{6}{|l|}{ Hémorhéomètre IF (\%):* } \\
\hline $\begin{array}{l}\text { Diabetic erythrocytes } \\
\quad(\text { No of experiments }=17)\end{array}$ & $100(6 \cdot 5)$ & NS & $100 \cdot 7(6 \cdot 3)$ & $<0.02$ & $104 \cdot 8(8 \cdot 0)$ \\
\hline $\begin{array}{l}\text { Normal erythrocytes } \\
\quad(\text { No of experiments }=17) \\
\text { Ektacytometer EI max: }\end{array}$ & $100(5 \cdot 2)$ & NS & $103.4(5.9)$ & $<0.01$ & $112 \cdot 4(8 \cdot 1)$ \\
\hline $\begin{array}{l}\text { Diabetic erythrocytes } \\
\quad(\text { No of experiments }=17)\end{array}$ & $0.56(0.01)$ & NS & $0.56(0.01)$ & NS & $0.56(0.01)$ \\
\hline $\begin{array}{l}\text { Normal erythrocytes } \\
\quad(\text { No of experiments }=17)\end{array}$ & $0.58(0.01)$ & NS & $0.58(0.01)$ & NS & $0.57(0.01)$ \\
\hline
\end{tabular}

${ }^{*}$ Results shown as a percentage in relation to the result at $5 \mathrm{mmol} / \mathrm{l}$ expressed as $100 \%$.

Table 4 Effects of inhibition of polyol pathway by Sorbinil $(5 \mu \mathrm{g} / \mathrm{ml})$ on filtration of erythrocytes from 17 healthy controls after incubation for two hours in hyperglycaemic buffer

\begin{tabular}{|c|c|c|c|c|c|}
\hline & \multicolumn{5}{|c|}{ Glucose concentration ( $\mathrm{mmol} / \mathrm{l}$ ) } \\
\hline & \multirow[t]{2}{*}{5} & \multirow[b]{2}{*}{$p$ value } & \multicolumn{3}{|l|}{50} \\
\hline & & & With Sorbinil & p value & Without Sorbinil \\
\hline Hémorhémètre IF $(\%)^{*}$ & $100(3 \cdot 5)$ & NS & $101 \cdot 1(3 \cdot 2)$ & $<0.001$ & $112.7(3.9)$ \\
\hline
\end{tabular}

added to erythrocytes from eight healthy controls and incubated for two hours in $50 \mathrm{mmol} / \mathrm{l}$ glucose there was no protective effect, IF increasing from $100 \%$ to $112.2 \%$ (SEM 6.6) without insulin and to $112.5 \%$ (6.3)\% with insulin.

Incubation at the three glucose concentrations in the above experiments caused no appreciable change after two hours in erythrocyte mean cell volume, mean cell haemoglobin concentration, or erythrocyte morphology.

\section{Discussion}

In clinical studies of erythrocyte deformability filtration through $3 \mu \mathrm{m}$ pores may be more sensitive to small changes in erythrocyte rheology than filtration through $5 \mu \mathrm{m}$ pores, ${ }^{2930}$ provided that erythrocyte mean cell volume does not change. ${ }^{22}$ It is also known that erythrocyte filtration techniques are highly sensitive to the presence of contaminating leucocytes in excess of $0.025 \times 10^{9} / 1 .^{18}$ The conflicting results of previous erythrocyte filtration studies in diabetes ${ }^{31-35}$ may therefore have been due to the use of $5 \mu \mathrm{m}$ diameter pores or to a variable degree of leucocyte contamination of the test erythrocyte suspensions, or both.
We therefore filtered a pure suspension of washed erythrocytes through $3 \mu \mathrm{m}$ diameter pores of both straight channel and tortuous channel type. No loss of filterability of diabetic erythrocytes through either type of membrane was found in the clinical study, even when poorly controlled patients were studied; this finding agrees with one previous study of $3 \mu \mathrm{m}$ diameter straight channel pores. ${ }^{36}$ Washed erythrocytes from diabetics in the steady state have also shown normal rheological behaviour in micropipette aspiration studies ${ }^{3738}$ and normal viscosity when measured at a high shear rate. ${ }^{39}$ Our results show that unwashed diabetic erythrocytes elongate normally when sheared in the Ektacytometer over a range of osmolalities from 80 to $500 \mathrm{mmol} / \mathrm{kg}$; this is again in agreement with a previous study. ${ }^{40}$

Our results were obtained using blood from 83 poorly controlled outpatient diabetics who had a mean blood glucose concentration of $12.2 \mathrm{mmol} / \mathrm{l}$ when venesected. We therefore studied the rheological effects of incubating erythrocytes in much higher concentrations of glucose. An appreciable reduction in $3 \mu \mathrm{m}$ pore filterability was obtained at 50 , but not at $25 \mathrm{mmol} / 1$ glucose, and the effect was greater for erythrocytes from normal subjects rather than from diabetics. Insulin had no rheologically pro- 
tective effect in vitro, in contrast to a previous report. ${ }^{2}$ Our in vitro incubations did not change the size, haemoglobin concentration, or shape of the erythrocytes. Alternative explanations for this loss of filterability of a pure suspension of washed erythrocytes include glycosylation of membrane protein, ${ }^{4142}$ or the intracellular accumulation of sorbitol via enhanced activity of the polyol pathway. ${ }^{43}$ The effect of sorbitol accumulation on erythrocyte cytoplasmic viscosity is unknown, however, although normal erythrocytes incubated in glucose in vitro have been reported to have decreased filterability. ${ }^{8}$ Our in vitro two hour incubation of normal erythrocytes in $50 \mathrm{mmol} / \mathrm{l}$ glucose resulted in a high intracellular concentration of sorbitol. When Sorbinil was added to the incubation buffer to prevent sorbitol accumulation there was no longer any appreciable loss of erythrocyte filterability. This substantiates the hypothesis that sorbitol accumulation has a rheological effect on erythrocytes, but, despite a 25 fold increase in sorbitol (to concentrations at least twice that found in poorly controlled diabetics) the loss of filterability through $3 \mu \mathrm{m}$ pores was only $12 \%-13 \%$. It would thus seem unlikely that sorbitol accumulation has an important role in the rheology of erythrocytes from poorly controlled outpatient diabetics, in whom we were unable to show any rheological abnormality by filtration or Ektacytometric methods.

We are indebted to United Birmingham Hospitals Trust Funds for a research grant; to Mr BL Cockrill, department of biochemistry, Solihull Hospital, for estimations of glycosylated haemoglobin; to Pfizer Central Research, Sandwich for providing Sorbinil and for financial support to PEJ; and to Mr R Passas, The Robens Institute, University of Surrey, for erythrocyte sorbitol measurements.

\section{References}

${ }^{1}$ Schmid-Schönbein H, Volger E. Red-cell aggregation and red-cell deformability in diabetes. Diabetes 1976;25(suppl 2):897-902.

${ }^{2}$ Juhan I, Vague Ph, Buonocore M, et al. Effects of insulin on erythrocyte deformability in diabetes-relationship between erythrocyte deformability and platelet aggregation. Scand J Clin Lab Invest 1981;41(suppl 156):159-64.

${ }^{3}$ Oughton J, Barnes AJ, Kohner EM. Diabetes mellitus: its effect on the flow properties of blood. Horm Metab Res (Supplement Series) 1981:11:112-20.

${ }^{4}$ Davidson RJL, Evan-Wong LA, Lean MEJ. The Coulter MCV in diabetic ketoacidosis. Clin Lab Haematol 1981;3:90-1.

${ }^{5}$ Evan-Wong LA, Davidson RJ. Raised Coulter mean corpuscular volume in diabetic ketoacidosis, and its underlying association with marked plasma hyperosomolarity. J Clin Pathol 1983; 36:334-6.

${ }^{6}$ Legge DG, Shortman K. Effect of pH on the volume, density and shape of erythrocytes and thymic lymphocytes. $\mathrm{Br} J$ Haematol 1968;14:323-35.
Bareford, Jennings, Stone, Baar, Barnett, Stuart

${ }^{7}$ Bock HA, Flückiger R, Berger W. Real and artefactual erythrocyte swelling in hyperglycaemia. Diabetologia 1985;28:335-8.

${ }^{8}$ Lugli R, Mambrini A, Codeluppi L, Peduzzi M, Salvioli G. Protein 으․ gylcosylation can affect red blood cell deformability in diabetes. IRCS Medical Science 1983;11:793-4.

${ }^{9}$ Galea G, Davidson RJL. The haemorheology of marathon run-ठ ning. Int J Sports Med 1984;6:135-8.

${ }^{10}$ Sachs JR, Knauf PA, Dunham PB. Transport through red cell $\frac{\bar{\sigma}}{\overline{0}}$ membranes. In: D MacN Surgenor, eds. The red blood cell. 2nd ed. Vol 2. New York: Academic Press, 1975:613-703.

${ }^{11}$ Sen $\mathrm{AK}$, Widdas WF. Determination of the temperature and $\mathrm{pH}_{\mathrm{Q}}$ dependence of glucose transfer across the human erythrocyte membrane measured by glucose exit. J Physiol 1962;160: $\overrightarrow{0}$ 392-403.

${ }^{12}$ Karlish SJD, Lieb WR, Ram D, Stein WD. Kinetic parameters of $\overrightarrow{\vec{\omega}}$ glucose efflux from human red blood cells under zero-trans conditions. Biochim Biophys Acta 1972;255:126-32.

${ }^{13}$ Morrison AD, Clements RS, Travis SB, Oski F, Winegrad AI 응 Glucose utilization by the polyol pathway in human erythrocytes. Biochem Biophys Res Commun 1970;40:199-205.

${ }^{14}$ Travis SF, Morrison AD, Clements RS, Winegrad AI, Oski FA. Metabolic alterations in the human erythrocyte produced by N increases in glucose concentration. The role of the polyol $N$ pathway. J Clin Invest 1971;50:2104-12.

${ }^{15}$ Malone JI, Knox G, Benford S, Tedesco TA. Red cell sorbitol. An $\rightarrow$ indicator of diabetic control. Diabetes 1980;29:861-4.

${ }^{16}$ Chylack LT, Kinoshita JH. A biochemical evaluation of a cataract induced in a high-glucose medium. Invest Ophthalmol Vis Sci 1969;8:401-12.

${ }^{17}$ Gabbay KH. Role of sorbitol pathway in neuropathy. Adv Metab Disord 1973;2(suppl):417-24.

${ }^{18}$ Morrison AD, Clements RS. Winegrad AI. Effects of elevated glucose concentrations on the metabolism of the aortic wall. J Clin Invest 1972;51:3114-23.

${ }^{19}$ Lucas GS, Caldwell NM, Kenny MW, et al. Effect of calciumchelating and non-chelating anticoagulants on erythrocyte and leucocyte filterability. Clinical Hemorheology 1983;3:451-67.

${ }^{20}$ Kenny MW, Meakin M, Stuart J. Methods for removal of leucocytes and platelets prior to study of erythrocyte deformability. 윽 Clinical Hemorheology 1983;3:191-200.

${ }^{21}$ Stuart J, Stone PCW, Bareford D, Caldwell NM, Davies JE, Baar? S. Evaluation of leucocyte removal methods for studies of eryth-O rocyte deformability. Clinical Hemorheology 1985;5:137-47.

${ }^{22}$ Stuart J, Stone PCW, Bareford D, Bilto YY. Effect of pore diameter and cell volume on erythrocyte filterability. Clinical 0 Hemorheology 1985;5:449-61.

${ }^{23}$ Lucas GS, Baar S, Caldwell NM, Stuart J. Comparison of silver and polycarbonate membranes for measurement of erythrocyte filterability. Clinical Hemorheology 1983;3:513-23.

${ }^{24}$ Hanss $M$. Erythrocyte filtrability measurement by the initial flowo rate method. Biorheology 1983;20:199-211.

${ }^{25}$ Bareford D, Stone PCW, Caldwell NM, Meiselman HJ, Stuart J D Comparison of instruments for measurement of erythrocyte deformability. Clinical Hemorheology 1985;5:311-22.

${ }^{26} \mathrm{Feo}$ C-J, Nossal M, Jones E, Bessis M. Une nouvelle technique d'étude de la physiologie des globules rouges: la mesure de leur $N$ déformabilité en fonction de l'osmolarité. Résultats obtenus par un Ektacytomètre automatisé sur du sang normal et dansç différentes anémies hémolytiques. Comptes Rendus deర l'Academie des Sciences (Paris) 1982;295:687-91.

${ }^{27}$ Bareford D, Stone PCW, Stuart J. Erythrocyte elongation in the Ektacytometer corrected for cell volume. Clinical Hemorheology $\mathbb{\Phi}$ 1985;5:429-35.

${ }^{28}$ Mallia AK, Hermanson GT, Krohn RI, Fujimoto EK, Smith PK. Preparation and use of a boronic acid affinity support forō separation and quantitation of glycosylated haemoglobins. (D) Analytical Letters 1981;14:649-61.

${ }^{29}$ Reinhart WH, Usami S, Schmalzer EA, Lee MML, Chien S. Evaluation of red blood cell filterability test: influences of pore size. $\sigma$ hematocrit level, and flow rate. J Lab Clin Med 1984;104:- 
501-16.

${ }^{30}$ Kovacs IB, O'Grady J. Prostacyclin increases filterability of normal and rigidified human red blood cells in vitro. Agents Actions Chemother 1984;14:306-10.

${ }^{31}$ Juhan I, Buonocore M, Vovan L, et al. Fitrabilité des hématies chez les diabétiques. Influence de la glycémie et variations après connection à un pancréas artificiel. Nouv Presse Med 1979;8:4083-5.

${ }^{32}$ Drouin P, Rousselle D, Stoltz J-F, et al. Study of blood viscosity and erythrocyte parameters in diabetic patients using an artificial pancreas. Scand J Clin Lab Invest 1981; 41(suppl): 165-9.

${ }^{33}$ Stuart J, Kenny MW, Aukland A, et al. Filtration of washed erythrocytes in atherosclerosis and diabetes mellitus. Clinical Hemorheology 1983;3:23-30.

${ }^{34}$ Hanss M, Attali JR, Helou C, Lemarie JC. Erythrocytes deformability and diabetes. Clinical Hemorheology 1983;3:383-91.

${ }^{35}$ Ritchie DM. Filtration of dilute erythrocyte suspension as a measure of erythrocyte deformability and its relationship to blood glucose control in diabetes mellitus. Clinical Hemorheology 1985;5:257-68.

${ }^{36}$ Rand PW, Norton JM, Barker ND, Richards AL, Lacombe EH, Pirone LA. Effects of diabetes mellitus on red cell properties. Clinical Hemorheology 1981;1:373-84.

${ }^{37} \mathrm{La}$ Celle PL. Behaviour of abnormal erythrocytes in capillaries. In: Coklet GR, Meiselman HJ, Brooks DE, eds. Erythrocyte mechanics and blood flow. Kroc Foundation Series Vol 13 New York: Alan R Liss, 1980:195-209.

${ }^{38}$ Sewchand LS, Hampel WL, Diddie KR, Meiselman HJ. Membrane mechanical properties of erythrocytes from patients with diabetic retinopathy. Microcirculation 1981-82;1:361-80.

${ }^{39}$ McMillan DE, Utterback NG. Impaired flow properties of diabetic erythrocytes. Clinical Hemorheology 1981;1:147-52.

${ }^{40}$ Adjizian JC. Pignon B, Poynard A. Ostermann G. Potron G. Clinical applications to the Ektacytometer. Clinical Hemorheology 1984;4:245-54.

${ }^{41}$ Miller JA, Gravallese E, Bunn HF. Nonenzymatic glycosylation of erythrocyte membrane proteins. Relevance to diabetes. $J$ Clin Invest 1980;65:896-901.

${ }^{42}$ Compagnucci P, Cartechini MG, Bolli G. et al. Hyperglycemia alters the physico-chemical properties of proteins in erythrocyte membranes of diabetic patients. Horm Metabol Res 1983;15: 263-8.

${ }^{43}$ Malone JI, Knox G, Harvey C. Sorbitol accumulation is altered in type 1 (insulin-dependent) diabetes mellitus. Diabetologia 1984;27:509-13.

Request for reprints to: Professor J Stuart, Department of Haematology, The Medical School, Vincent Drive, Birmingham B152TJ, England. 